International Journal of Business Management and Economic Review

Vol. 4, No. 02; 2021

ISSN: 2581-4664

\title{
THE EFFECT OFEDUCATION PRICE AND SERVICE QUALITY ONSTUDENT EDUCATION SELECTION DECISION AND ITS IMPACT ON STUDENT SATISFACTION :STUDY IN ACEHMALAHAYATI SHIPPING POLYTECHNIC
}

\author{
*Denny Adi Setyawan, Said Musnadi and Teuku Roli Ilhamsyah Putra \\ Management Department, UniversitasSyiah Kuala, Indonesia \\ http://doi.org/10.35409/IJBMER.2021.3250
}

\begin{abstract}
This study intends to examine the effect of price and service quality on student decision in choosing education and training and its impact on the satisfaction of training students at shipping polytechnics in Aceh. This research was conducted on training participants (students) of the Aceh Malahayati Shipping Polytechnic training program throughout 2019 with a population of 16,917 people. The sampling technique used was the probability sampling technique, which was the stratified random sampling in order to obtain a sample of 200 students. Data were analyzed using Structural Equation Modeling (SEM) with the help of Amos software. The research found that the price of education and the quality of service were the factors that influenced the student education selection decision. Furthermore, the price of education, quality of service, and student education selection decisionare factors that affect student satisfaction. The results of the mediation test found that student education selection decision significantly mediates the effect of education price on student satisfaction, and are proven to function as a partial mediator. Meanwhile, student education selection decision cannot significantly mediate the effect of service quality on student satisfaction at the Aceh MalahayatiShipping Polytechnic. The novelty of this research lies in the combination of previous theories regarding the effects of direct causality and the effects of mediating causality, as well as new research object. The next researchers are expected to form a new model as a result of the development of this research model that has been tested, by combining it with other variables such as brand image, trust, and E-WOM, and gender in the multigroup moderation model will provide a more complete picture.
\end{abstract}

Keyword:education price, service quality, student education selection decision, satisfaction.

\section{INTRODUCTION}

Education has an important role in ensuring the development and sustainability of life in all fields. Through education, there will be an increase in the quality of human resources who are able to develop science and technology and perform work in accordance with industrial needs in the global market. The need for educated, trained, qualified and skilled human resources in the maritime industry at the national and global levels is still experiencing shortages and it is predicted that it will not be fulfilled in the next 5 years. With the implementation of STCW 1978 Amendment 2010 will have an impact on the demand for training needs in the maritime sector, both skills and expertise training in which Indonesian seafarers both inside and outside the country will follow the updating according to the applicable provisions. 


\section{International Journal of Business Management and Economic Review}

Vol. 4, No. 02; 2021

ISSN: 2581-4664

The Aceh Malahayati Shipping Polytechnic as one of the Technical Implementing Units of the Transportation Human Resources Development Agency under the Ministry of Transportation has the main task and function of organizing basic and middle-level maritime education and training following the Regulation of the Minister of Transportation PM 27 of 2019. The establishment of the Aceh Malahayati Shipping Polytechnic aims to provide access for Maritime communities in the western region of Indonesia, especially the Aceh and northern parts of Sumatra, to get the opportunity to get education and training in the field of shipping.

With the development of science and technology which is increasing rapidly nowadays, it requires the world of education to be skilled and creative in increasing its ability to produce quality education. Important factors for achieving success for a company can be identified by analyzing what our customers want and need. Therefore, institutions that provide guided education services must be skilled and creative in increasing their ability to produce quality education with various marketing mixes that must be considered to achieve student satisfaction.(Wijaya, 2016)argued that Customer satisfaction with educational services is one of the determinants of the success of the educational competition.

In line with the theory above, student satisfaction, or what we also call training participants, will not occur if the training participants do not decide to use the services offered by educational institutions. This is felt directly in the process of providing educational services provided by the Aceh Malahayati Shipping Polytechnic, gradually the trend that has been experienced to date, the acceptance of training participants is in line with the satisfaction of the services received by these individuals. This trend will tend to decline when viewed from the ability of the Aceh Malahayati Shipping Polytechnic in completing the incorrect number of educational certificates in time and several other problems that have resulted in disappointment for individuals/students who wish to take this type of education and training. So that a temporary thread can be drawn while the first step in creating training participant satisfaction is to establish effective strategies to lure students to decide to choose the educational services offered. In addition, training participants are also always faced with material obligations in the form of price or tuition rate which is considered quite high. The backgrounds of training participants are very diverse. In general, the economic backgrounds of the training participants come from lower to middle-level economies.

In this connection, school management needs to manage financial management carefully, correctly, and wisely, for example through the cross-subsidy mechanism and others. So that the students from all backgrounds of economic ability are placed proportionally. The price or rate of education is a sensitive factor among students, especially for tertiary institutions whose segments are low and middle-class training participants(Rahbat Lupiyoadi, 2013). In research (Hasanuddin, 2016)stated that price has an effect on customer satisfaction but not significant. In line with these two opinions, the cost is a factor that greatly influences the decision level of choosing the type of education and training service in a maritime Technical Service Unit (UPT). Broadly speaking, students who are actors and users of the type of educational services are sailors who are not bound by contracts so that their costs or budgets are limited. Therefore naturally, actors or students who will choose a type of education and training for maritime education services will consider the number of direct costs (education) and indirect costs such as living costs during education, accommodation, etc. which of course will affect the level of costs incurred by students. 


\section{International Journal of Business Management and Economic Review}

Vol. 4, No. 02; 2021

ISSN: 2581-4664

In general, students are always accompanied by rights and authorities, including the right to obtain quality services in the field of education, both in the provision of software and hardware. For this reason, all academic instruments must be well integrated and coordinated, as a whole it must always be directed and directed at efforts to provide quality education services, so that it will have a positive impact on the satisfaction of students, given the satisfaction of students will encourage enthusiasm of students to learn. Quality is often defined as the state of an object or position compared to something else such as a set standard. When the quality of the facilities owned is in accordance with the standard or above, the education service is considered competent. Current demands on education service providers are not only limited to the ability to produce graduates that are measured academically but also throughout the program. In addition, higher education institutions must be able to prove high quality supported by existing accountability so that it can lead to various higher education choices as consideration for prospective students.

The concept of the cost rate policy for education and training, the fulfillment of the quality of education and training services which can affect the level of satisfaction of students so that it will directly affect the increase in quantity It is hoped that through the high quality of education services and affordable education price, it will increase the satisfaction of students, which encourages their enthusiasm for learning, so that with this high enthusiasm for learning, the alumni of the Aceh Malahayati Shipping Polytechnic, will become sailors who reliable, which can utilize all the potential of the Indonesian sea solely for the benefit of the progress of the nation and the State.

The problem that arises is when the quantity of graduate students, competency training, and Seafarers' Skills training which is owned by the Aceh Malahayati Shipping Polytechnic, has continued to decline until early 2019 , this can also be seen from the report on the realization of revenue achievement from the resources (PNBP and BLU sector) of the Aceh Malahayati Shipping Polytechnic. Realization of revenue in this year is still low compared to the revenue target that has been set, this is due to the low realization of participants in maritime training towards the target participants that have been determined.

Moving on from the aforementioned phenomena as well as a written report on the data of enthusiasts and the income of the Aceh Malahayati Shipping Polytechnic, the authors think it is necessary to reveal whether there is a significant influence from the elements of education price $\&$ service quality of Aceh Malahayati Shipping Polytechnic, on student decision in choosing the education provided by Aceh Malahayati Shipping Polytechnic, and its impact on the student satisfaction on that education, so that it can be a reference for increasing the number of graduate outputs and the number of admissions of the Pelayaran Polytechnic in Aceh.

\section{LITERATURE STUDY Student Satisfaction}

(Jiradilok, Malisuwan, Madan, \& Sivaraks, 2014)explained that satisfaction is the result of comparing previous expectations with the perceptions of customer product performance. (Khan, Rizwan, Islam, Aabdeen, \& Rehman, 2016)argueD that satisfaction is a summary of the psychological state of the consumer that is generated when emotional expectations are met which is associated with cosmic feelings about previous experiences. Meanwhile(Tjiptono, 2017)mentioned that the situation of dissatisfaction occurs after consumers use the product or 


\section{International Journal of Business Management and Economic Review}

Vol. 4, No. 02; 2021

ISSN: 2581-4664

experience the service purchased and feel that the product's performance does not meet expectations. Dissatisfaction can lead to negative attitudes towards brands and their manufacturers/service providers.

From some of the definitions of satisfaction above, it can be concluded that satisfaction is a feeling of whether someone is happy or not after comparing the results obtained with the desired expectations. In this research, we tried to test several dominant factors which were expected to have an impact on the satisfaction of students (training participants) at the Aceh Malahayati Shipping Polytechnic through the institution service quality, the education price (cost), and the student'sstudent education selection decision(purchasing decision). In this study, the measurement of satisfaction is carried out using indicators as disclosed by(Kotler\& Armstrong, 2017)namely products/services that provide benefits, communication with customers, services provided following what is desired, costs incurred following customer expectations and ease of transactions.

\section{Purchasing Decision (Student education selection decision)}

The consumer purchasing decisionis a series of consumer choices made before making a purchase when they have the desire to buy(Rivai\& Sagala, 2014). (Kotler \& Keller, 2018)explained that there are five stages in the purchase decision process, namely problem recognition, information search, alternative evaluation, purchase decision, and post-purchase behavior (satisfaction and loyalty). (Sudaryono, 2014)stated that the decision-making process begins with a need that tries to be fulfilled.

From the literature above, it can be concluded that purchasing decisionis a series of processes of action on the need for a desired product or service. Consumers do not necessarily determine a choice of products or services, in this case choosing education, many considerations are made by students in choosing educational institutions, one of which is the quality of service and the cost of education. In this research, the measurement of student education selection decision uses indicators as disclosed by(Fahriansyah\& Zubir, 2015)namely needs, recommendations, comparisons, quality, recommendations, costs, and locations.

\section{Service Quality}

Quality is often defined as the state of the object or position compared to something else, such as comparing the quality of education services from several places of education with a set standard. When more than the standard or equal to the standard, the education service is called competent or quality The existence of quality of education services is a guide to the nature of the services provided that matches or exceeds the expectations and satisfaction of its customers both express and implied.(Chairunnisa, 2018)explained that the quality of education services is the effort of educators and education personnel in implementing services to students, parents, and other communities which are their responsibility based on the quality and results of their work.

Yani (2011) in(Chairunnisa, 2018)stated that the current demands for educational institutions are not only limited to the ability to produce graduates that are measured academically but also throughout the program. Besides, higher education institutions must be able to prove high quality supported by existing accountability so that it can lead to various higher education choices as consideration for prospective students. Meanwhile(Zeithaml, Bitner, \& Gremler, 2018)stated that Service Quality is the customer's perception of the service 


\section{International Journal of Business Management and Economic Review}

Vol. 4, No. 02; 2021

ISSN: 2581-4664

components of a product, and is also an important determinant in achieving customer satisfaction.

Service quality education is something dynamic related to products, services, people, and the environment that meet or exceed expectations known as quality. Apart from that, it was found that quality is the standard performance expected by the customer(Goetsch\& Davis, 2000). Quality of service as mentioned by(Parasuraman, Zeithaml, \& Berry, 1988)has several dimensions, namely tangibility, reliability, responsiveness, assurance, and empathy.

From some of the definitions above, it can be understood that service quality is a component of service provided to consumers through consumer perceptions. Consumers will judge for themselves the services provided according to their expectations or not, if appropriate, the services provided are of quality. In this study the indicators used for service quality variable for the Aceh Malahayati Shipping Polytechnic are as follows: (1) Use of infrastructure, (2) Social interaction, (3) Understanding of students, (4) Speed of response in services, (5) Accuracy, (6) Reliability (7) Convenience.

\section{Education Price}

Price is closely related to the product, whereas cost is more closely related to the services provided(Hermawan, Hadiwidjojo, Rofiaty, \& Solimun, 2014). The price or cost of education is a sensitive factor among students, especially for universities whose segments are lower and middle-class students(Rambat Lupiyoadi \& Hamdani, 2011). Meanwhile(Kotler\& Keller, 2012)stated that price is one element of the income-generating marketing mix; other elements generate costs. From a firm's perspective, the reference price is used when the company compares the actual selling price with internal and external reference price(Hsu \& Pham, 2015).

Price is one of the factors that have a major role in the consumer decision-making process. Pricing can help buyers decide how to allocate their purchasing power across different types of goods and services. Thus, price is the amount of money paid by consumers to buy a product or service for profit(Hermawan et al., 2014). (Kotler \& Armstrong, 2017)explained that there are several methods that can be used to set a price, namely pricing based on value, researching price based on costs, and pricing based on competitors.

From some of the literature regarding the price above, the price is a component that determines the product or service which reflects the value of the product or service offered to consumers. Price is a core component in marketing services, especially in educational institutions, where students will consider an educational institution between one another through the cost factor or the price of the services offered. In this study, price measurement using indicators as disclosed by(Fahriansyah\& Zubir, 2015)namely the suitability of price with the quality of educational services, efficiency/price competitiveness, the accuracy of costs incurred, the suitability of costs with student abilities, and flexibility.

\section{Conceptual Framework}

This research conceptual framework will explain the relationship between each variable on increased loyalty, which can be described as follows : 


\section{International Journal of Business Management and Economic Review}

Vol. 4, No. 02; 2021

ISSN: 2581-4664

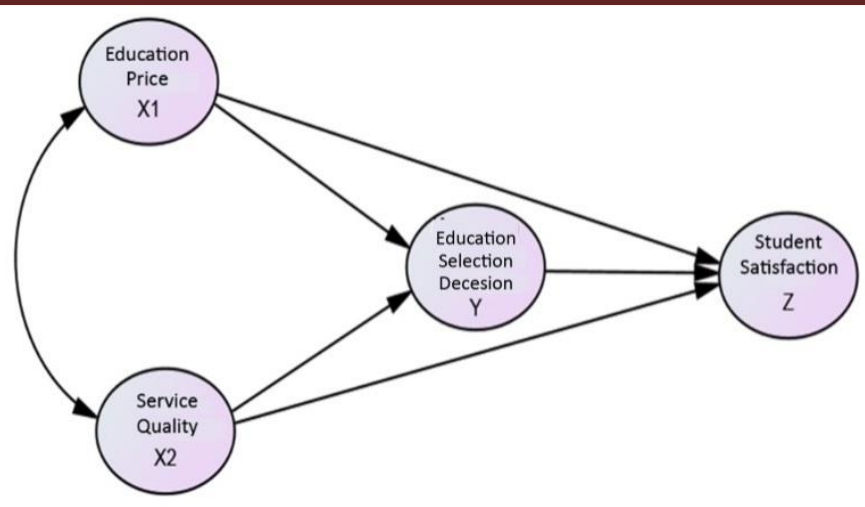

Figure 1.Conceptual Framework

H1: There is an effect of education price on student satisfaction at the Aceh Malahayati Shipping Polytechnic.

H2: There is an effect of Service Quality on student satisfaction at the Aceh Malahayati Shipping Polytechnic.

H3: There is an effect of student education selection decisionon student satisfaction at the Aceh Malahayati Shipping Polytechnic.

H3: There is an influence of education price on student education selection decisionat the Aceh Malahayati Shipping Polytechnic.

H4: There is an effect of service quality on student education selection decisionat the Aceh Malahayati Shipping Polytechnic.

H6: There is an indirect effect of the education price on student satisfaction through student education selection decision at the Aceh Malahayati Shipping Polytechnic.

H7: There is an indirect effect of Service Quality on student satisfaction through student education selection decision at the Aceh Malahayati Shipping Polytechnic.

\section{RESEARCH METHOD}

This research was conducted at the Aceh Malahayati Shipping Polytechnic. While the object of this research is the education price, quality of service, education selection decision, and satisfaction of students from Aceh and North Sumatra in theEducation and Training program at the Aceh Malahayati Shipping Polytechnic. The population determined in this study was the students/training participants of the Aceh Malahayati Shipping Polytechnic Training and Education throughout 2019, totaling 16,917 people. In this study, the sampling method uses probability sampling techniques where all members of the population have the same opportunity to be selected as samples. The sample taken was some of the Seafarers' Training and Education from Aceh and North Sumatra at the Malahayati Aceh Polytechnic.

Based on existing population data, to calculate the number of sample selected used the theory of Hair et al (2013), where the minimum sample is 5-10 x the number of parameters (indicators). The parameters in this study used $5 \mathrm{x}$ the number of indicators or $5 \mathrm{x} 24$ so that the minimum number of sample that can be used in this study was 120 respondents. To meet the needs of a sample that was comprehensive or representative of the population, the sample in this study was determined to be 200 students. The data used in this study was primary data. Data 
International Journal of Business Management and Economic Review

Vol. 4, No. 02; 2021

ISSN: 2581-4664

collection in this study was carried out by using a questionnaire distribution technique.

The data analyzed used in this research is Structural Equation Modeling (SEM) with the help of the Amos program. Hypothesis testing in this research is carried out in two stages, namely direct hypothesis testing and indirect hypothesis testing. Indirect hypothesis testing is carried out by referring to opinions(Baron \& Kenny, 1986)with procedures developed by(Sobel, 1982).

\section{RESULTS AND DISCUSSION}

Direct Hypothesis Testing

The structural model analysis explaining the effect test between variables is presented in the following path diagram:

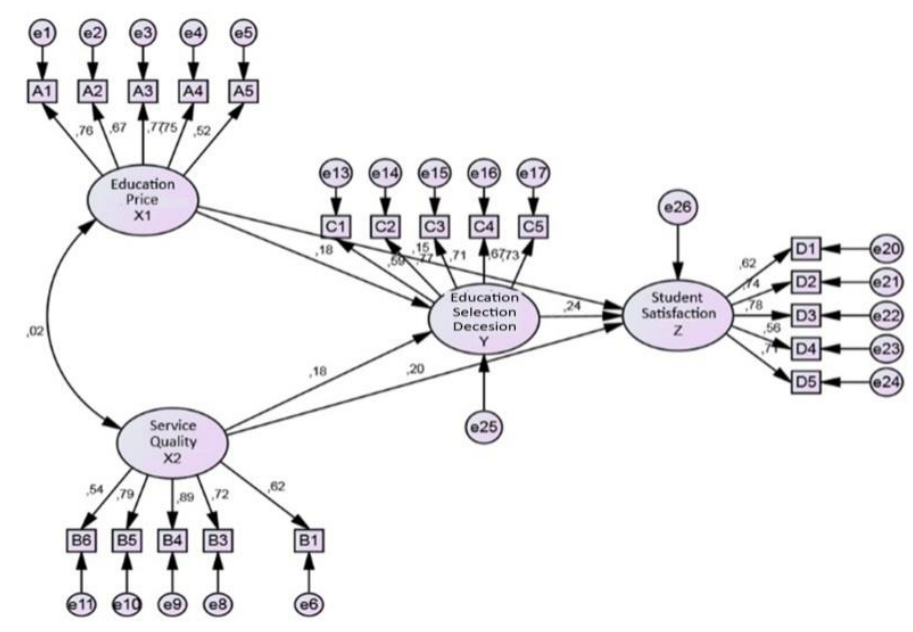

Figure 2.Regression Weight of Structural Equational Model (Rounded Value)

The full model test results for testing the direct effect hypothesis after fulfilling the SEM assumptions are more clearly shown in the following table:

Table 1. Hypothesis Test Results

\begin{tabular}{|c|c|c|c|c|c|c|c|}
\hline \multirow[b]{2}{*}{ Endogenous } & & \multirow[b]{2}{*}{ Exogenous } & \multicolumn{2}{|l|}{ Estimate } & \multirow[b]{2}{*}{ S.E. } & \multirow[b]{2}{*}{ C.R. } & \multirow[b]{2}{*}{ Sig } \\
\hline & & & $\begin{array}{l}\text { Unstanda } \\
\text { rd }\end{array}$ & $\begin{array}{l}\text { Standar } \\
\text { d }\end{array}$ & & & \\
\hline $\begin{array}{l}\text { Student Education } \\
\text { Selection Decision }\end{array}$ & $<-$ & Education Price & 210 & 249 & .073 & 2.856 & .004 \\
\hline $\begin{array}{l}\text { Student Education } \\
\text { Selection Decision }\end{array}$ & $<-$ & Service quality & .168 & .184 & .077 & 2.194 & .028 \\
\hline Student Satisfaction & $<-$ & Education Price & .148 & .174 & .073 & 2.033 & .042 \\
\hline Student Satisfaction & $<-$ & Service quality & .174 & .188 & .077 & 2.258 & .024 \\
\hline Student Satisfaction & $<-$ & Student & .253 & .250 & .093 & 2.711 & .007 \\
\hline
\end{tabular}


International Journal of Business Management and Economic Review

Vol. 4, No. 02; 2021

ISSN: 2581-4664

\begin{tabular}{|l|l|l|l|l|l|l|}
\hline \hline Endogenous & Exogenous & $\begin{array}{l}\text { Estimate } \\
\text { Unstanda Standar } \\
\text { rd }\end{array}$ & S.E. & C.R. & Sig \\
\hline & $\begin{array}{l}\text { Education } \\
\text { Selection } \\
\text { Decision }\end{array}$ & & & & & \\
\hline
\end{tabular}

Source: Primary data, 2020 (processed)

By looking at the test results in table 2, the analysis can be explained as follows:

1. H1: The test of the effect of education price on student satisfaction obtained the value of Critical Ratio (C.R) is 2.033> 1.960 at a significant level of $0.042<0.05$. Thus, it can be stated that the price of education has a significant effect on student satisfaction at Aceh Malahayati Shipping Polytechnic. This means that the suitability of the price offered with the benefits obtained will result in students being satisfied. These results support previous research conducted by(Rizal, Adam, \& Ibrahim, 2017)which states that price has an effect on post-purchase satisfaction. Education costs affect student satisfaction(Hermawan et al., 2014). Price has a significant effect on customer satisfaction(Cristo, Saerang, \& Worang, 2017). Price has a significant effect on customer satisfaction(Foster, 2016). Price affects customer satisfaction(Konuk, 2019). Price was found to be a stronger determinant of satisfaction(Calisir, Basak, \& Calisir, 2016). The results of this study reject the research conducted by(Hasanuddin, 2016)which stated that the price affects customer satisfaction is positive, but not significant.

2. H2: The test of the effect of service quality on student satisfaction obtained the value of Critical Ratio (C.R) of $2.258<1.96$ at a significant level of $0.024<0.05$. Thus, it can be stated that the quality of service has a significant effect on student satisfaction in choosing education at the Aceh Malahayati Shipping Polytechnic. This means that the quality of service applied at the Shipping Polytechnic affects student satisfaction. These results support previous research conducted by(Dora, 2018)which stated that service quality has a significant effect on student satisfaction. other than that(Cristo et al., 2017),(Foster, 2016),(Farooq, Salam, Fayolle, Jaafar, \& Ayupp, 2018),(Ju, Back, Choi, \& Lee, 2019),dan(Jiang \& Zhang, 2016)also revealed that Service Quality significantly affects customer satisfaction. Service Quality was found to be a stronger determinant of satisfaction(Calisir et al., 2016)and service quality has a positive and significant effect on customer satisfaction(Hasanuddin, 2016).

3. H3: The test of the effect of student educationselection decision on student satisfaction obtained the value of Critical Ratio (C.R) of $2.711<1.96$ at a significant level of 0.007 $<0.05$. Thus, it can be stated that the election decision has a significant effect on student satisfaction at Aceh Malahayati Shipping Polytechnic. Student's decision in choosing an education following their expectations can create satisfaction for students. These results support previous research conducted by(Rizal et al., 2017)which stated that the purchase decision has an effect on satisfaction. student satisfaction and purchasing decision have a significant relationship(Dora, 2018). Purchase decision has a significant effect on customer satisfaction(Hasanuddin, 2016). Customer purchasing decision has a significant effect on customer satisfaction(H. Susanto, 2013). 
International Journal of Business Management and Economic Review

Vol. 4, No. 02; 2021

ISSN: 2581-4664

4. H4: The test of the effect of the price of education on the student educationselectiondecisionobtained the Critical Ratio (C.R) value of $2.856<1.960$ at a significant level of $0.004<0.05$. Thus, it can be stated that the price of education has a significant influence on the student educationselectiondecisionat the Aceh Malahayati Shipping Polytechnic. This means that the affordability of the education price that is applied can influence student decision to choose the desired education. These results support previous research conducted by(Rizal et al., 2017). Price affects purchasing decision. Student's decision to remain active Learning re-learning is the implication of the variable tuition fees(Dora, 2018). There is a positive relationship between price and consumer purchasing behavior (an appropriate price makes consumers more willing to buy goods)(Al-Salamin\& Al-Hassan, 2016). Price affects consumer decision(Hasanuddin, 2016). The results showed that costs influence studentdecision in choosing to study(Fahriansyah\& Zubir, 2015).

5. H5: The test of the effect of service quality on student educationselectiondecisionobtained the value of Critical Ratio (C.R) worth $2.194<1.960$ at a significant level of $0.028<0.05$. Thus, it can be stated that the quality of service has a significant influence on the decision to choose education at the Aceh Malahayati Shipping Polytechnic. This means that the quality of service applied to the Shipping Polytechnic actually can influence student decision to choose education according to their desires. These results support previous research conducted by(Dora, 2018)which stated that the student's decision to remain active in relearning is the implication of the Service Quality variable. Service quality has a positive and significant effect on purchasing decision(Hasanuddin, 2016). These results indicate that the quality of education services greatly determines students in choosing the desired education, good quality of service is the hope of all students in choosing education

\section{Indirect Hypothesis Testing (Mediation)}

The results of testing the indirect hypothesis (mediation) are described below:

1. H6: Testing the indirect effect of education price on student satisfaction through student educationselection decision can be described as follows:

X1-Y- Z

\begin{tabular}{|c|c|c|c|c|}
\hline Input: & & Test statistic: & Std. Error: & $p$-value: \\
\hline a 0.210 & Sobel test: & 1.97657555 & 0.02687982 & 0.04808963 \\
\hline$b 0.253$ & Aroian test: & 1.91639611 & 0.02772391 & 0.0553147 \\
\hline$s_{\mathrm{a}} 0.073$ & Goodman test: & 2.04280538 & 0.02600835 & 0.04107171 \\
\hline$s_{b} 0.093$ & Reset all & \multicolumn{3}{|c|}{ Calculate } \\
\hline
\end{tabular}

Figure 3. Results of Hypothesis Mediation Effects 6 
International Journal of Business Management and Economic Review

Vol. 4, No. 02; 2021

ISSN: 2581-4664

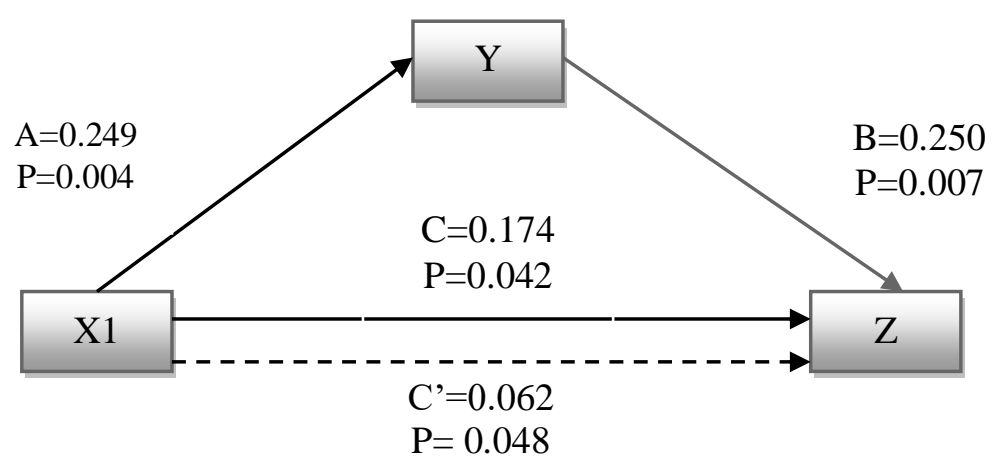

Figure 4. The results of the Mediation Test on the Price of Education-Student education selection decision-Student satisfaction

\section{Information:}

$\mathrm{X} 1=$ Price of Education (Exogenous Variable)

$\mathrm{Y}=$ Student education selection decision (Mediation Variable)

$\mathrm{Z}=$ Student Satisfaction (Exogenous Variable)

$\mathrm{A}=$ Coefficient of influence $\mathrm{X} 1$ to $\mathrm{Y}$

$\mathrm{B}=$ Coefficient of Influence $\mathrm{Y}$ to $\mathrm{Z}$

$\mathrm{P}=$ probability or significant value

The picture above can be explained that the price of education has a significant effect on job satisfaction, the price of education has a significant effect on student satisfaction and the student education selection decision has a significant effect on student satisfaction, thus it is considered partial mediation. To prove that partial mediation is significant or not, it can be seen from the results of the mediation test (line- $C$ ') through the Sobel test that a significant value of 0.048 is less than 0.05 . The results of this study indicate that the variable effect of price on student satisfaction is significantly mediated by the student education selection decision. The results of this study support the research conducted by(Rizal et al., 2017)which stated that the indirect effect of price, on post-purchase satisfaction through purchasing decision. The indirect effect of price on customer satisfaction through positive and significant purchasing decision(Hasanuddin, 2016). This study shows that an appropriate education fee will have an indirect impact on student satisfaction through the student educationselection decision. After making the selection of education, students will consider the suitability of the costs of education with what is expected, and then they will feel satisfied or not, if the costs incurred are appropriate, with expectations then the students will be satisfied and vice versa if the costs incurred are not appropriate then the students are not satisfied.

2. H7: testing the indirect effect of service quality on student satisfaction through student education selection decision can be described as follows. 
International Journal of Business Management and Economic Review

Vol. 4, No. 02; 2021

ISSN: 2581-4664

X2-Y-Z

\begin{tabular}{|c|c|c|c|c|}
\hline Input: & & Test statistic: & Std. Error: & $p$-value: \\
\hline a 0.168 & Sobel test: & 1.70204181 & 0.02497236 & 0.08874753 \\
\hline$b \longdiv { 0 . 2 5 3 }$ & Aroian test: & 1.63610255 & 0.02597881 & 0.10181813 \\
\hline$s_{\mathrm{a}} 0.077$ & Goodman test: & 1.77665541 & 0.0239236 & 0.07562495 \\
\hline$s_{\mathrm{b}} 0.093$ & Reset all & & Calculate & \\
\hline
\end{tabular}

Figure 5.Results of Hypothesis Mediation Effects 7

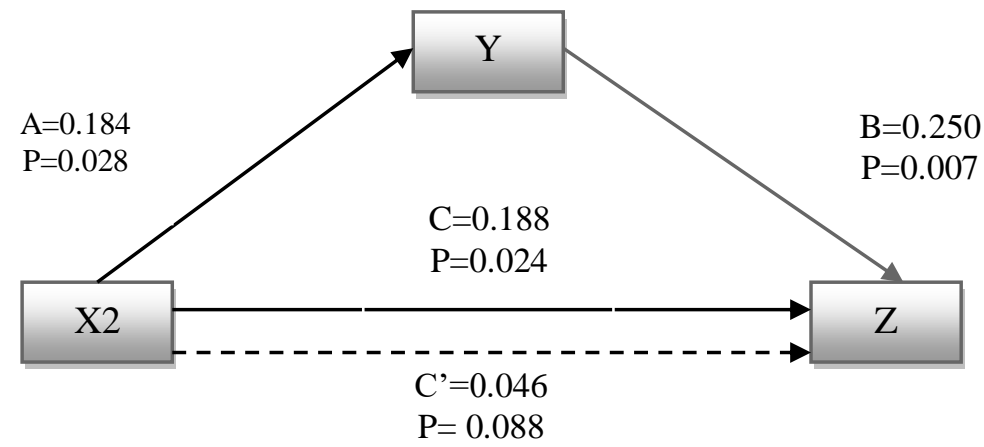

Figure 6.The result of the Mediation test of service quality-job satisfaction-student satisfaction

\section{Information:}

$\mathrm{X} 2$ = Service Quality (Exogenous Variable)

$\mathrm{Y}=$ Student education selection decision (Mediation Variable)

$\mathrm{Z}=$ Student Satisfaction (Exogenous Variable)

$\mathrm{A}=$ Coefficient of influence $\mathrm{X} 2$ to $\mathrm{Y}$

$\mathrm{B}=$ Coefficient of Influence $\mathrm{Y}$ to $\mathrm{Z}$

$\mathrm{P}=$ probability or significant value

The picture above can be explained that service quality has a significant effect on student education selection decision, student education selection decisionhas a significant effect on student satisfaction and service quality has a significant effect on student satisfaction. Thus, it is considered partial mediation. To prove that partial mediation is significant or not, it can be seen from the results of the mediation test (line-C ') through the Sobel test that a significant value of 0.088 is greater than 0.05 at the 5\% significant level. The results of this study indicate that the variable influence of service quality on student satisfaction is not significantly mediated by the student education selection decision. The results of this study reject the research conducted by(Hasanuddin, 2016)which stated that service quality has a positive and significant indirect effect on customer satisfaction through purchasing decision. For consumers who want to buy a product, the services provided when choosing until the purchase transaction is very important. 
International Journal of Business Management and Economic Review

Vol. 4, No. 02; 2021

ISSN: 2581-4664

\section{CONCLUSION}

The results of research on students/training participants of the Aceh Malahayati Shipping Polytechnic found that the price of education and the quality of service were the factors that influenced the student education selection decision. Furthermore, the price of education, quality of service, and the attitude of student education selection decision are factors that affect student satisfaction. The results of the mediation test found that student education selection decisionsignificantly mediates the effect of education price on student satisfaction, and student education selection decision function as a partial mediator. Meanwhile, student education selection decision cannot significantly mediate the effect of service quality on student satisfaction in choosing education and training at the Malahayati Aceh Polytechnic. All of these findings contribute to the field of science and can become a reference for practice managers, especially in targeting the number of students at the Aceh Malahayati Shipping Polytechnic.

Several recommendations can be mapped from the research results. To increase student satisfaction at the Malahayati Aceh Poltekpel, the leadership needs to improve the quality of service. The quality of service can be improved through increasing the use of infrastructure (facilities \& infrastructure to support the education and training) at the Aceh Malahayati Shipping Polytechnic which is more optimal for the smoothness of the teaching and learning process. Students at Poltekpel should emphasize more on practicum or internship, this is necessary so that students can train their abilities not only in theory but also practically in the field so that they can compete in the world of work. In terms of providing services to the teaching and learning process, the intensity of teaching through videos or movies about tricks and techniques visually relevant will make it easier for students to easily digest or understand.

For future research, it is better to complement this research by including a moderating variable in the model it is building. The application of a pure moderation model, especially for brand image, trust, and E-WOM, as well as gender in a multigroup moderation model will provide a more complete picture not only to complete references in the field of marketing science, especially relating to consumer behavior but also to provide more insight. in providing input for Poltkepel leaders in the decision-making process that makes Aceh Malahayati Shipping Polytechnic one of the leading Shipping Polytechnic in Indonesia.

\section{REFERENCES}

Al-Salamin, H., \& Al-Hassan, E. (2016). The Impact of Pricing on Consumer Buying Behavior in Saudi Arabia; Al-Hassa Case Study. European Journal of Business and Management, 5(4), 1-16. https://doi.org/10.20525/ijrbs.v5i4.551

Baron, R. M., \& Kenny, D. A. (1986). The Moderator-Mediator Variable Distinction in Social Psychological Research: Conceptual, Strategic, and Statistical Considerations. Journal of Personality and Social Psychology, 51(6), 1173-1182.

Calisir, N., Basak, E., \& Calisir, F. (2016). Key drivers of passenger loyalty: A case of Frankfurt-Istanbul flights. Journal of Air Transport Management, 53, 211-217. https://doi.org/10.1016/j.jairtraman.2016.03.002

Chairunnisa, C. (2018). The Effect of Brand Image And Quality Of Educational Services On Customer Satisfaction. Jurnal Manajemen, 22(3), 325-339. 
International Journal of Business Management and Economic Review

Vol. 4, No. 02; 2021

ISSN: 2581-4664

https://doi.org/http://dx.doi.org/10.24912/jm.v22i3.425

Cristo, M., Saerang, D., \& Worang, F. (2017). The Influence of Price, Service Quality, and Physical Environment on Customer Satisfaction. Case Study Markobar Cafe Mando. Jurnal EMBA, 5(2), 678-686.

Dora, Y. M. (2018). Service Quality and Education Cost Implication the Decision to Stay Active Re-Study Mediated by Student Satisfaction - A Study at Private University in West Java. European Journal of Economics and Business Studies, 10(1), 200. https://doi.org/10.26417/ejes.v10i1.p200-207

Fahriansyah, \& Zubir, E. (2015). Analisis Pengaruh biaya dan Lokasi Terhadap keputusan Mahasiswa Memilih Universitas Terbuka (Studi Pada mahasiswa UPBJJ-UT Pontianak). Jurnal Ekonomi Integra, 5(1), 32-50. https://doi.org/https://doi.org/10.51195/iga.v5i1.95

Farooq, M. S., Salam, M., Fayolle, A., Jaafar, N., \& Ayupp, K. (2018). Impact of service quality on customer satisfaction in Malaysia airlines: A PLS-SEM approach. Journal of Air Transport Management, 67(December 2017), 169-180. https://doi.org/10.1016/j.jairtraman.2017.12.008

Foster, I. B. (2016). The Effect of Price and Service Quality on Customer Satisfaction in Mutiara Hotel Bandung. American Research Journal of Humanities and Social Sciences, 2016. https://doi.org/10.21694/2378-7031.16008

Goetsch, D. L., \& Davis, S. B. (2000). Quality Management. Introduction to Total Quality Management for Production, Processing, and Services. London: Prentice-Hall Inc.

H. Susanto, A. (2013). The influence of customer purchase decision on customer satisfaction. Jurnal Emba, 1(4), 1659-1666.

Hasanuddin, M. (2016). Analysis of the Influence of Service Quality, Location and Price on Customer Satisfaction through Purchasing Decisions as Intervening Variables in Sales of Gold Precious Metal. Jurnal Riset Bisnis Dan Manajemen, 4(1), 49-66.

Hermawan, D., Hadiwidjojo, D., Rofiaty, \& Solimun. (2014). Higher Education Image and Cost: The Effects and Impacts on Student Satisfaction and Trust (A Study On Private University Students Majoring In Ict In Indonesia). International Journal of Economic Practices and Theories, 4(4), 455-465.

Hsu, Y., \& Pham, H. (2015). Effects of Reference Pricing on Customer Purchasing Intention. International Review of Management and Business Research, 4(4), 1156-1170.

Jiang, H., \& Zhang, Y. (2016). An investigation of service quality, customer satisfaction and loyalty in China's airline market. Journal of Air Transport Management, 57, 80-88. https://doi.org/https://doi.org/10.1016/j.jairtraman.2016.07.008

Jiradilok, T., Malisuwan, S., Madan, N., \& Sivaraks, J. (2014). The Impact of Customer Satisfaction on Online Purchasing: A Case Study Analysis in Thailand. Journal of Economics, Business and Management, 2(1), 5-11. https://doi.org/10.7763/JOEBM.2014.V2.89

Ju, Y., Back, K. J., Choi, Y., \& Lee, J. S. (2019). Exploring Airbnb service quality attributes and their asymmetric effects on customer satisfaction. International Journal of Hospitality Management, 77(November 2017), 342-352. https://doi.org/10.1016/j.ijhm.2018.07.014 
Khan, M. N., Rizwan, M., Islam, F., Aabdeen, Z.-U.-, \& Rehman, M. (2016). The Effect of Brand Equity of Mobile Phones on Customer Satisfaction: An Empirical Evidence from Pakistan. American Journal of Business and Society, 1(1), 1-7.

Konuk, F. A. (2019). The influence of perceived food quality, price fairness, perceived value and satisfaction on customers' revisit and word-of-mouth intentions towards organic food restaurants. Journal of Retailing and Consumer Services, 50(March), 103-110. https://doi.org/10.1016/j.jretconser.2019.05.005

Kotler, P., \& Armstrong, G. (2017). Principles of Marketing (17th ed.). London: Pearson.

Kotler, P., \& Keller, K. L. (2012). Marketing Management (14th ed.). London, UK: Pearson Education.

Kotler, P., \& Keller, K. L. (2018). Marketing Management, Global Edition (15th editi). Harlow, United Kingdom: Pearson.

Lupiyoadi, Rahbat. (2013). Competency Based Service Marketing Management (3rd ed.). Jakarta: Salemba Empat.

Lupiyoadi, Rambat, \& Hamdani, D. A. (2011). Service marketing management (Ed. 2). Jakarta: Salemba Empat.

Parasuraman, A. P., Zeithaml, V. A., \& Berry, L. L. (1988). SERVQUAL: A multiple- Item Scale for measuring consumer perceptions of service quality. Journal of Retailing, 64(1 Spring), 12-40.

Rivai, V., \& Sagala, E. J. (2014). Human Resource Management for Companies: From Theory to Practice (3rd ed.). Jakarta: Rajawali Pers.

Rizal, F., Adam, M., \& Ibrahim, M. (2017). Effect of Price, Design and Location on Decision of Purchase and Its Implication on Customer Satisfaction. International Journal of Economics, Commerce and Management, V(12), 345-353.

Sobel, M. E. (1982). Asymptotic Confidence Intervals for Indirect Effects in Structural Equation Models. Sociological Methodology, 290-321. https://doi.org/https://doi.org/10.2307/270723

Sudaryono. (2014). Consumer Behavior in a Marketing Perspective. Jakarta: Lentra Ilmu Cendiaka.

Tjiptono, F. (2017). Marketing strategy (4th ed.). Jakarta: Andi.

Wijaya, D. (2016). Marketing of Educational Services (Cet. 1). Jakarta: Bumi Aksara.

Zeithaml, V., Bitner, M. J., \& Gremler, D. (2018). Services Marketing: Integrating Customer Focus Across the Firm (7th ed.). New York: McGraw-Hill. 